\title{
Mineralogical, Geotechnical Characterization and Stability of the Cut Slopes of Widikum and its Surroundings (North-West Cameroon)
}

\author{
Oscar Rodrigue Michel Kenmoe ${ }^{1}$, Valentine Katte Yato $^{2}$, Francois Ngapgue ${ }^{3} \&$ Armand Sylvain Ludovic \\ Wouatong ${ }^{1}$ \\ ${ }^{1}$ Department of Earth Sciences, Faculty of Science, University of Dschang, P.O Box 67 Dschang, Cameroon \\ ${ }^{2}$ Department of Civil Engineering and Forestry Techniques, HTTTC, University of Bamenda, P.O Box 39 Bambili, \\ NWR, Cameroon \\ ${ }^{3}$ Department of Civil Engineering, Fotso Victor Institute of Technology, University of Dschang, Cameroon \\ Correspondence: Armand Sylvain Ludovic Wouatong, Department of Earth Sciences, Faculty of Science, \\ University of Dschang, P.O Box 67 Dschang, Cameroon. E-mail: aslwouat@yahoo.com
}

Received: June 19, 2018

Accepted: June 28, 2018

Online Published: August 28, 2018

doi:10.5539/esr.v8n1p1

URL: https://doi.org/10.5539/esr.v8n1p1

\begin{abstract}
The Widikum highlands and its surroundings are located in the North West Region of Cameroon. These five last years, landslides are frequently affecting movement on this portion of the highway. An investigation for understanding the mechanism of these phenomena was recently performed to clarify and to propose suitable remediable solutions. The study included mineralogical and geotechnical characterization of the local soil materials. The X-ray diffraction mineralogical analysis on clay fractions reveals the presence of phyllitic minerals (kaolinite, gibbsite, montmorillonite, illite and biotite). Associated minerals are mainly represented by quartz. Montmorillonite has the small crystal and largest surface which aid in increasing its adsorptive capacity. Clayed minerals can cause swelling and consequently the change or variation of the mechanical characteristics of the materials. The natural water content of weathered products vary from 27 to $47.4 \%$ which are close or even lower than the liquid limit included between 59.4 and $71.9 \%$, this justify their unstable character. In addition, the high plasticity index ranges between 17.9 and $29.3 \%$ and is indicative of plastic materials thus very sensitive to creep. Moreover, the saturation ratio is very high $(60-96 \%)$ thus attesting to their quasi saturated state. It is advisable to reduce the height of the steps to $2.3 \mathrm{~m}$ by opting for a bench of $3 \mathrm{~m}$ and adopting an inclination angle of $\beta=37.5^{\circ}$. Building retaining structures as well as eucalyptus and vertiva grass planting is recommended to reduce landslide incidences.
\end{abstract}

Keywords: Widikum, landslides, highlands, mineralogical characteristics, geotechnical characteristics

\section{Introduction}

The Cameroon Volcanic Line, direction $\mathrm{N} 30^{\circ} \mathrm{E}$ and $1600 \mathrm{~km}$ long, forms a series of horst and graben, comprising the Bamenda Mountains and it is marked by a succession of volcanic, plutonic and metamorphic formations resting on the crystalline base subject to intensive weathering. Therefore, these are also dominated by three great geomorphological units varying between 250 and $1550 \mathrm{~m}$ laid out in successive steps and separated by more marked escarpments (steep slopes greater than $45^{\circ}$ ) favorable to instabilities. Yet, relatively few scientific data is available on the causes of these instabilities. The main objective of this study is to analyze the stability of Widikum and its surroundings cut slopes by means of the mineralogical and geotechnical studies and to propose suitable remediable solutions. Landslides represent a major threat to human life, constructed facilities, and infrastructure in most mountainous regions of the world (Delmas et al. 1987; Lulseged et al. 2005; Zangmo et al. 2009; Kouayep et al. 2009). They are controlled by diversity of factors such as substratum composition, geotechnical parameters of the whole lithological and pedological set up, climatic conditions, geometry and geomorphology of the site (Delmas et al. 1987). Very often, human activities are reported to increase slope instability and the likelihood that subsequent rainfall will trigger landslides. Landslides that have so far been recorded have caused a number of damages. In Nepal, in 2015, landslides buried several villages and caused 400 deaths. The case of the slip of Aab Bareek, which occurred on May 02, 2014 in the Badakhchan region in Afghanistan, gives a report of 300 dead and 4000 people displaced. We can also mention that which took place in 1978, 1985, 1986, 1990 and 1998 at Yaoundé, in 1998 at Nkongsamba, and in 2003 at Poli. That of Kekem, on the night of October 20, 2007 killed one person 
and caused many damages. The investigation of this study is based on the mineralogy and geotechnical characteristics of weathered products in order to infer the causes of landslides in a tropical humid area. For this purpose, a comprehensive set of mineralogical (constituent of weathered products) and geotechnical tests (grain size distribution, Atterberg limits, unit weight and shear strength) were carried out.

\section{Location of Study Area and Geological Setting}

\subsection{Location of Study Area}

The study area is situated in the North-West Region of Cameroon. It is located between latitudes $05^{\circ} 49^{\prime} 12^{\prime \prime}$ and $05^{\circ} 54^{\prime} 12^{\prime \prime}$ of the Northern Hemisphere and longitudes 09 $42^{\prime} 00^{\prime \prime}$ to $09^{\circ} 50^{\prime} 00^{\prime \prime}$ East. It comprises the following (figure. 1) villages: Bajem, Befang and Bamben in the North, Widikum in the Center, Diche I in the South, Diche, Denku and Numba in the West and of Tiben and Numben in the East.

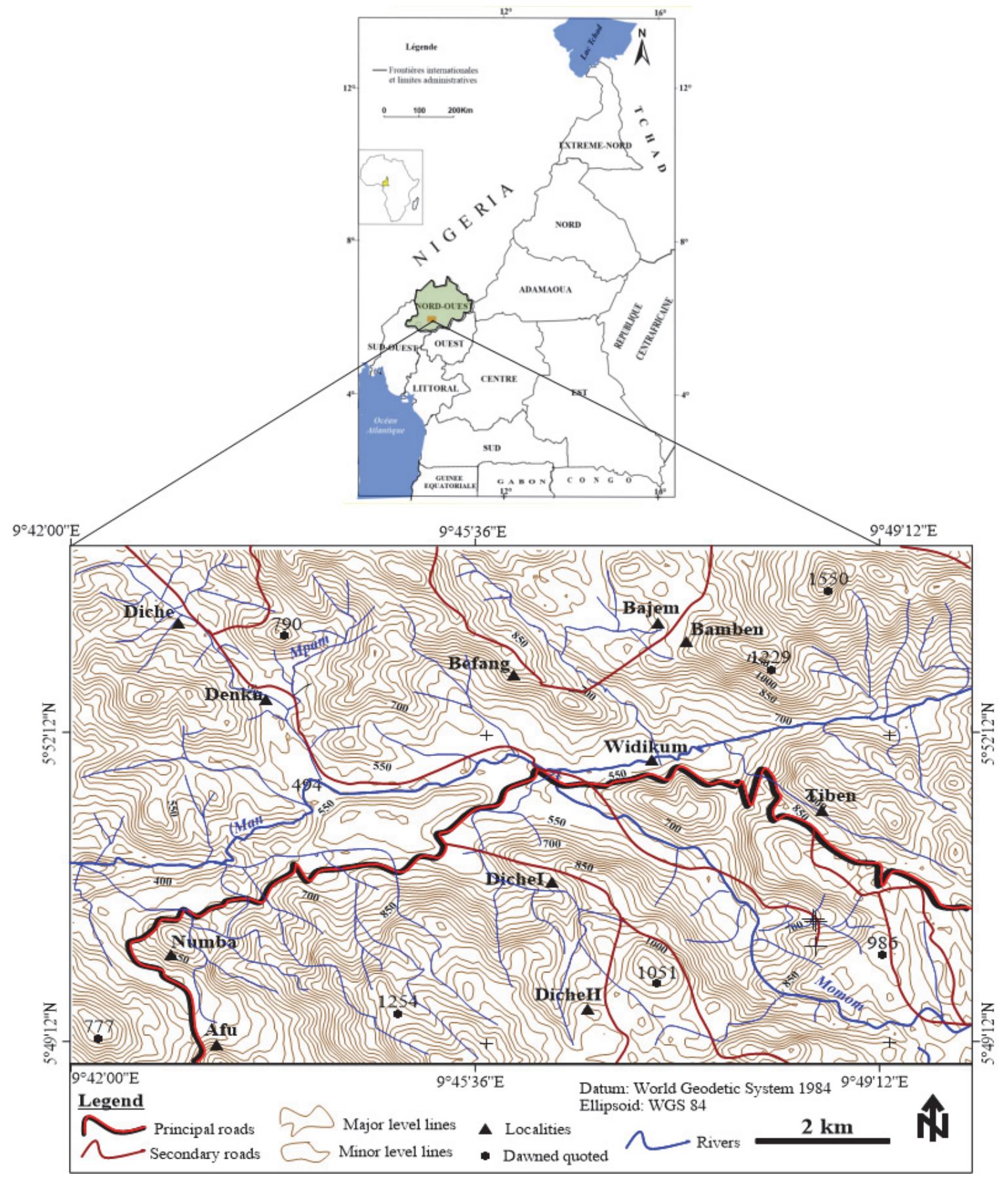

\subsection{Geological Setting}

Figure 1. Location of the study area 
The Widikum environs lies between two climatic zones which are the humid tropical equatorial rainforest climate in the Mamfe basin and the dry savannah climate of the Bamenda highlands frequently affected by landslides. The rainfall records are high with an annual average of $2703.32 \mathrm{~mm}$. These rainfalls have a significant action on the chemical destabilization of the surface and subsurface materials. Moreover, the hydrographical network is subdendritic type. Water has a remarkable influence on the weathering and therefore, create structural disequilibrium (erosion and cracks) due to the collapse of huge saturated materials made up of brown aluminous lateritic soils resulting from the volcanic products (old basalts) and plutonic (faded granite) on one hand and gray maroon andosols resulting from the recent volcanic products made up of columnar prims of basalts on other. Furthermore, three great geomorphological units are listed (figure. 2).The low zone $(250-800 \mathrm{~m})$ is vast and slightly corrugated and marked by a softer relief. The median zone $(800-1300 \mathrm{~m})$ corresponds to a higher projecting plateau and is marked by the juxtaposition of the morphological characteristics suitable for the low and the high altitude zone. The high altitude zone (1300 $\mathrm{m}$ and more) occupy the summit of the study area in which the relief is dominated by interfluves.

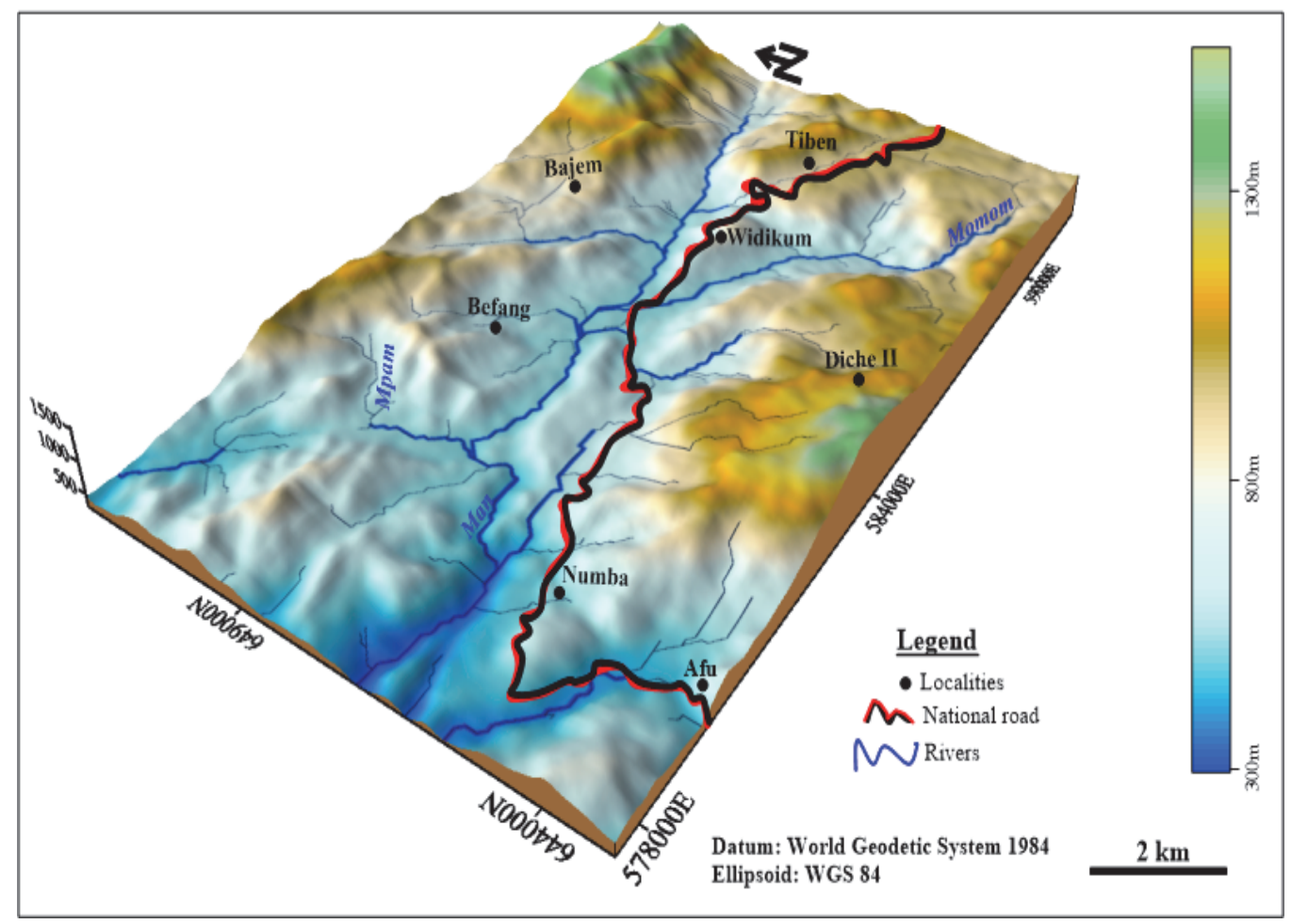

Figure 2. Geomorphological units of the study area

However, the landscape map (figure. 3) presents six different slope classes. The $0-7 \%$ and $7-12 \%$ classes represent approximately $27 \%$ and correspond to the flat landscapes. These landscapes occupy the base of valleys or depressions and are consequently liable to floods due to the lack of adequate drainage network. The $12-18 \%$ and $18-23 \%$ classes, constitutes the undulating landscape and represents a percentage of about $35 \%$. Finally, the $23-29 \%$ and $29-48 \%$ of slope classes constutite the bulk, of the slope classes making up $48 \%$ of the landscape and which are favorable to landslides and other natural disasters. 


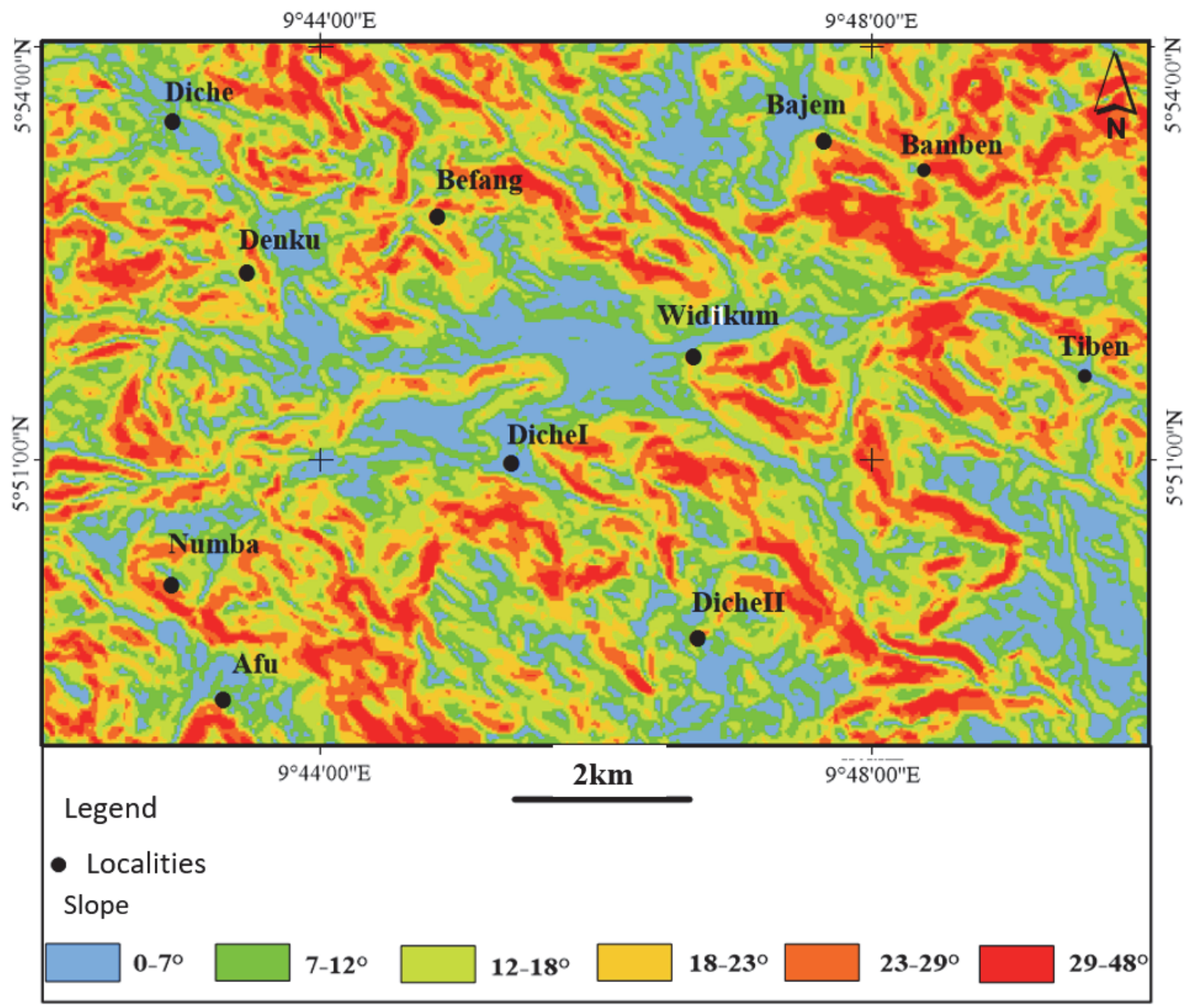

Figure 3. Slope map of the study area

\section{Materials and Methods}

\subsection{Profiling}

Soil profiling was carried out on the cut slopes resulting from road construction activities of each of three sites of study area namely Fifty One, Ofen Tiben and Ogwei Tiben. Macroscopic descriptions were performed on each soil profile followed by specimen test collection labeled WD1, WD2, WD3, WD4, WD5, WD6 and WD7 at the upper, median and lower assemblage, for mineralogical and geotechnical analysis. On the whole, seven undisturbed samples were taken using PVC tubes of length $25 \mathrm{~cm}$ and of diameter $20 \mathrm{~cm}$. Therefore, WD1 and WD2 represented the upper and lower assemblages specimen respectively from weathered basalt and granite materials of Fifty One. Then, WD3, WD4 and WD5 those coming from the upper, median and lower assemblages of Ofen Tiben weathered granite with phenocristal of feldspar. Finally, WD6 and WD7 are the specimens resulting from the upper and lower assemblage of Ogwei Tiben made up of weathered gneiss with amphibole and biotite.

\subsection{Mineralogical Analysis}

The mineralogical composition of the materials was studied using X-ray diffractometer. The samples were first heated at $105{ }^{\circ} \mathrm{C}$ for 24 hours before being crushed and sieved through an $80 \mu \mathrm{m}$ diameter sieve at the AGEs laboratory of the Department of Geology of University of Liege. The measuring apparatus used was MARK BRUKER diffractometer, using radiation $\mathrm{CuK} \alpha\left(5^{\text {th }}=1.518 \AA\right)$. The scanned angular domain was $5^{\circ} \leq 2 \theta \leq 90^{\circ}$ with an angular space of $0.020^{\circ}$, within 6 seconds and at an ambiant temperature of $25^{\circ} \mathrm{C}$. The apparatus was connected to a computer which directly gave the diffractograms. The different peaks of the diffractograms were determined with the aid of data automatically furnished by the Diffrac + software and controlled manually by ASTM cards. 


\subsection{Geotechnical Analysis}

The geotechnical analysis (natural water content, Atterberg limit, unit weight, triaxial shear strength,) were performed on specimen collected and sealed in plastic bags then transported to the National Civil Engineering Laboratory (LABOGENIE) of Yaounde (Cameroon). The natural water content was determined by drying in an oven at $105^{\circ} \mathrm{C}$ for 24 hours according to the French Standard Norm NF P 94-050 (1995). However, the liquid limit was determined using the Casagrande method while the plastic limit was identified on the rods of $10 \mathrm{~cm}$ length and about $3 \mathrm{~mm}$ of thickness according to the French Standard Norm NF P 94-051 (1991). These Atterberg limits were used to determine the plasticity index of the weathered products. Thus, Ip $=\omega_{\mathrm{L}}-\omega_{\mathrm{P}}$ where Ip is the plasticity index; $\omega_{\mathrm{L}}$ the liquid limit and $\omega_{\mathrm{P}}$ represents the plastic limit. Moreover, the unit weight was determined using the pycnometer method according to the French Standard Norm NF P 94-054 (1991). The, dry density, porosity, void ratio and the saturation ratio were determined using the relationships between physical characteristics of soils. There are expressed according to the formulas 1,2,3 and 4 below.

$$
\begin{aligned}
\gamma_{d} & =\frac{\gamma}{1+W} \\
n & =\frac{\gamma_{s}-\gamma_{d}}{\gamma_{s}} \times 100 \\
e & =\frac{n}{1-n}
\end{aligned}
$$

and

$$
S_{r}=\frac{w \gamma_{r}}{e \gamma_{w}}
$$

respectively where $\gamma_{d}$ is the unit weight of dry soil, $\gamma$ the apparent unit weight of soil, $\gamma_{s}$ the unit weight of solid particles, $\boldsymbol{w}$ a water content, $\gamma_{\boldsymbol{w}}$ the unit weight of water, $\gamma_{r}$ the unit weight of soil, $\boldsymbol{e}$ the void ratio and $\boldsymbol{n}$ the porosity. Finally, the unconsolidated and undrained triaxial shear tests were carried out according to French Standard Norm NF P 94-074 (1994) enable to determine the friction angle and the cohesion of weathered products. It was carried out in three stages: sample preparation and installation in a triaxial cell, then saturation and finally shearing of the sample. After shearing of the specimen, respective stress curve $\tau_{\max }=\mathrm{f}\left(\sigma_{\max }\right)$ were established from which the friction angle and the cohesion of weathered products were obtained. Finally the critical height step of slopes was determined according to Taylor-Biarez expression in Philipponnat \& Hubert (1997) to determine the long term stability of the slopes by means of the formula 5 below.

$$
\mathrm{H}_{\mathrm{c} 1}=2.67 \frac{\mathrm{c}}{\gamma} \tan \left(45^{\circ}+\frac{\phi}{2}\right)
$$

If the plateforms limited by a slope is intended to be subjected to a uniformly distributed surchage $\mathrm{q}$, the critical height of each step will be given according to the relation 6 below

$$
\mathrm{H}_{\mathrm{c} 2}=2.67 \frac{\mathrm{c}}{\gamma} \tan \left(45^{\circ}+\frac{\phi}{2}\right)-\frac{2 \mathrm{q}}{\gamma}
$$

where $\boldsymbol{c}$ is the internal cohesion, $\gamma$ the unit weight of soil, $\boldsymbol{\Phi}$ the friction angle and $\boldsymbol{H}_{\boldsymbol{c}}$ the critical height respectively.

\section{Results}

\subsection{Outline of Landslide and Soil Profile Characteristics}

Three localities namely Fifty One, Ofen Tiben and Ogwei Tiben were affected by landslides. Firstly, the Fifty One locality knew a translational and rotational soil slip (figure. 4a) located between coordinates $05^{\circ} 51^{\prime} 02.7$ " North and $09^{\circ} 45^{\prime} 08.2$ " East at an altitude of $632 \mathrm{~m}$. Rupture has a width of $8 \mathrm{~m}$, a height of at least $8 \mathrm{~m}$ over a length from approximately $10 \mathrm{~m}$. This constitutes a slip material of volume $\mathrm{V}=640 \mathrm{~m}^{3}$. Several factors caused this movement: the nature of the involved rock made up of partially faded basalt, the morphology of the site at the top of a lengthened interfluve with steep slope on granitic base almost completely faded with clay-sandy tendency. In addition, the presence of crack (figure. 4b) due to the water infiltration and finally the presence of water on the walls of the slope (figure. $4 \mathrm{c}$ ) due to lack of adequate drainage. We can also notice the stratification plan on weathered material (figure $4 \mathrm{~d}$ ). 

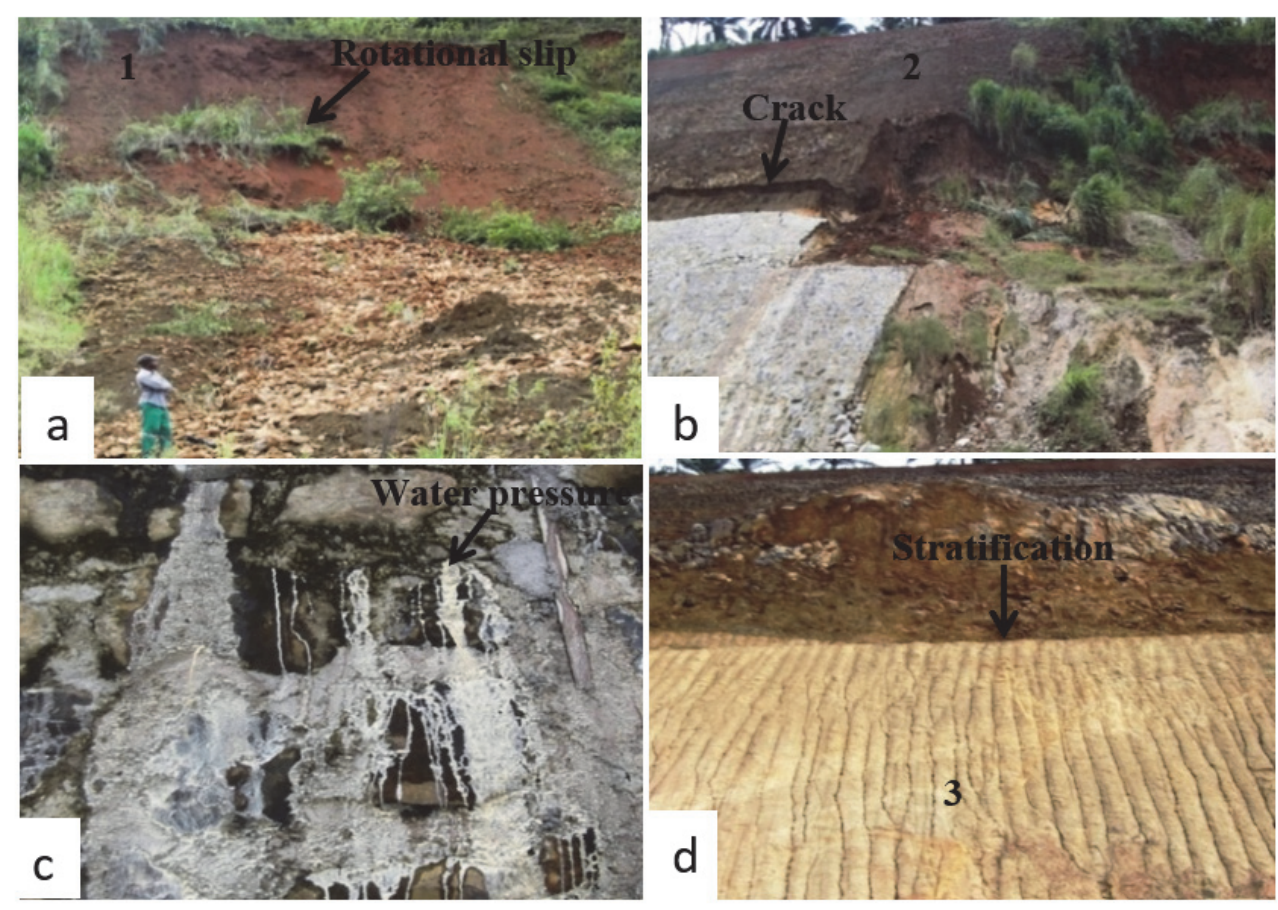

Figure 4. Outline of the Fifty One site. (a): translational and rotational slip. (b): crack. (c): water pressure. (d): stratification on weathered materials. (1): dark red to brown gravelly matrix. (2): basaltic matrix. (3): greyish matrix

Secondly, the translational soil slip which occurred on weathered materials of Ofen Tiben (figure. 5) is located between coordinates $05^{\circ} 51^{\prime} 39.8^{\prime \prime}$ North and $09^{\circ} 46^{\prime} 45.1^{\prime \prime}$ East, at an altitude of $602 \mathrm{~m}$. This movement is due to several factors: initially, the nature of the bed rock made up of porphyroid granite with biotite, hornblende and phenocristal of feldspar partially faded and presenting many fractures. These materials are on the flank of relatively rounded interfluve with steep slopes combined with their low resistances due to their low compactness. Lastly, the fine grain size materials of clayey consistency, with the permanent presence of water on the surface of the slope constitutes predisposition factors.

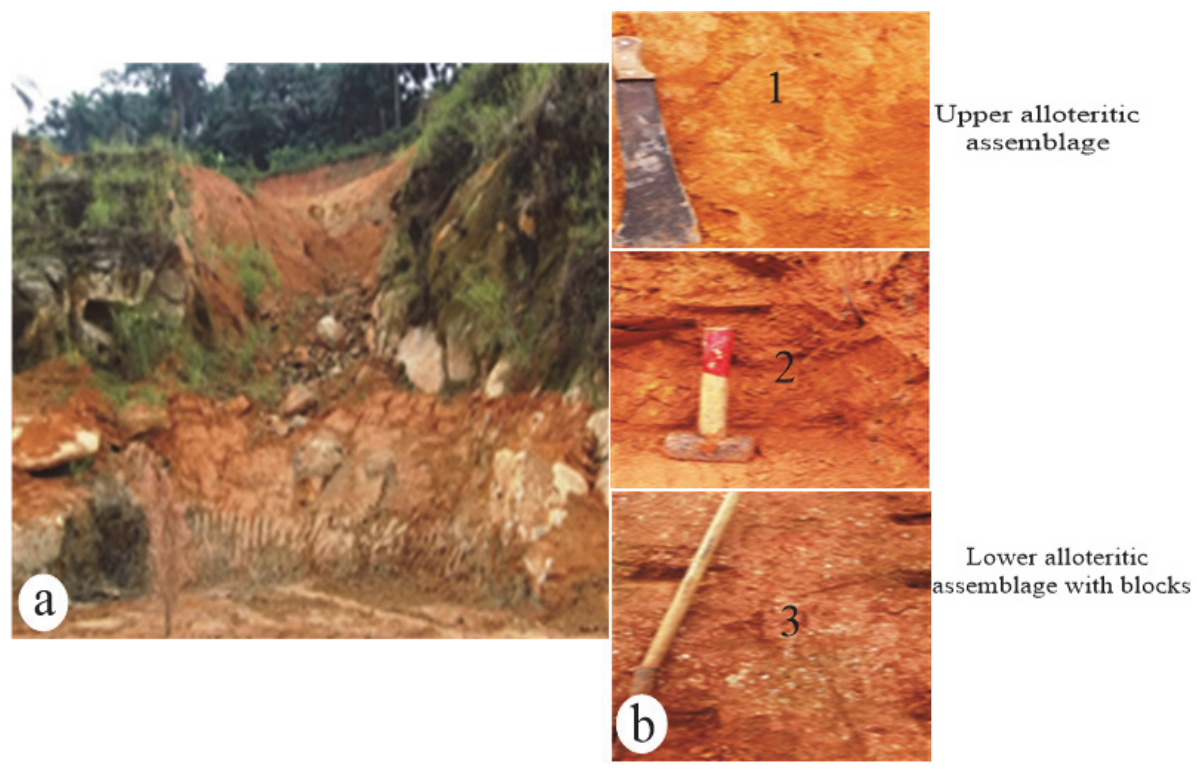

Figure 5. a) Panoramic sight of Ofen Tiben soil slip. b) soil profile (1): red yellowish matrix. (2): red matrix. (3): brown blade matrix 
Finally, a translational landslide occurred at Ogwei Tiben site (figure. 6) with coordinates $05^{\circ} 51^{\prime} 49.5^{\prime \prime}$ North and $09^{\circ} 47^{\prime} 26.5^{\prime \prime}$ East and at an altitude of $618 \mathrm{~m}$. The cut has a width of approximately $6 \mathrm{~m}$, a height of at least $4 \mathrm{~m}$ and a length of $7.5 \mathrm{~m}$. Thus, the volume of the slip material is estimated to be $180 \mathrm{~m}^{3}$. Several factors caused this movement. The nature of the bed rock is made up of gneiss with amphibole and biotite almost completely faded. The geomorphology of the site on the flank of the interfluve consist of abrupt slopes combined with the low cohesion and friction angle of weathered materials due to their heterogeneity with clayey consistency.

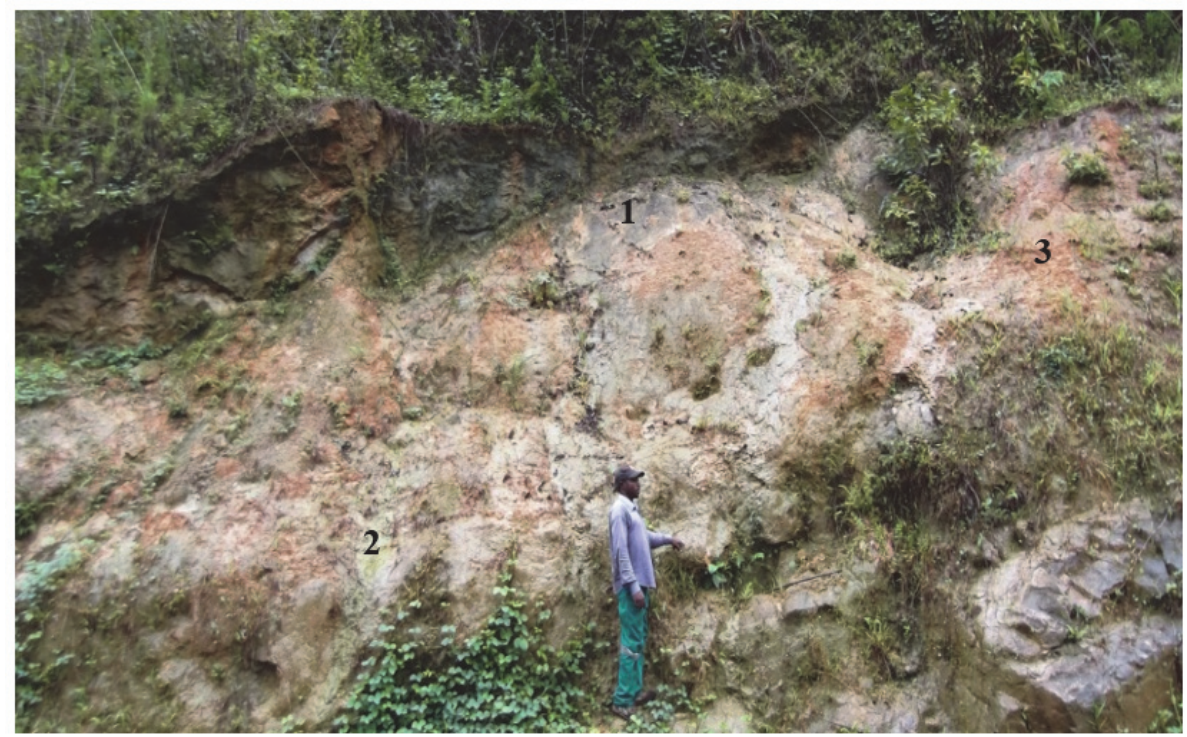

Figure 6. Panoramic view of Ogwei Tiben soil slip. (1): light gray matrix. (2): whitish matrix. (3): yellowish red matrix

\subsection{Mineralogical Features}

The X-ray diffraction mineralogical analysis on weathered materials of Fifty One (figure. 7) reveals that the upper assemblage consists of phyllitic minerals (kaolinite, gibbsite) and associated minerals such as quartz, hematite and goethite. Meanwhile, the lower assemblage consists of phyllitic minerals (kaolinite, illite, muscovite and biotite) and associated minerals such as quartz and hematite.

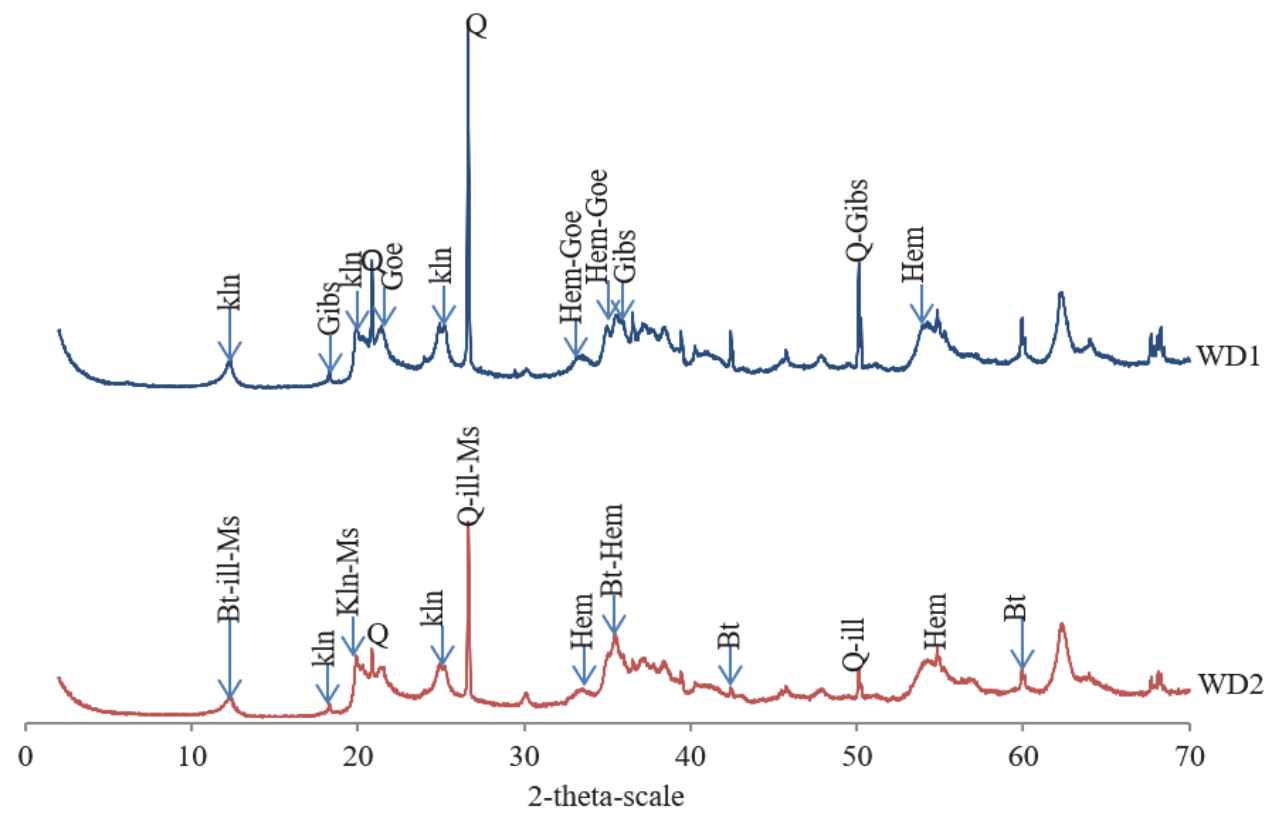

Figure 7. XRD patterns of mineral constituents of Fifty One weathered materials

ill $=$ illite. $\mathbf{K l n}=$ kaolinite. Gibs $=$ gibbsite. $\mathbf{Q}=$ quartz. $\mathbf{H e m}=$ hematite. $\mathbf{B t}=$ biotite. $\mathbf{G o e}=$ goethite. $\mathbf{M s}=$ muscovite 
Furthermore, the X-ray diffraction mineralogical analysis on weathered materials of Ofen Tiben (figure. 8) shows that the upper assemblage consists of phyllitic minerals (kaolinite, gibbsite, biotite and illite) and associated minerals (quartz). Meanwhile, that of median assemblage consist of phyllitic minerals (kaolinite, illite, gibbsite, biotite and montmorillonite) and associated minerals namely quartz. The lower assemblage consists of phyllitic minerals (illite, kaolinite, gibbsite and montmorillonite) and associated minerals (quartz).

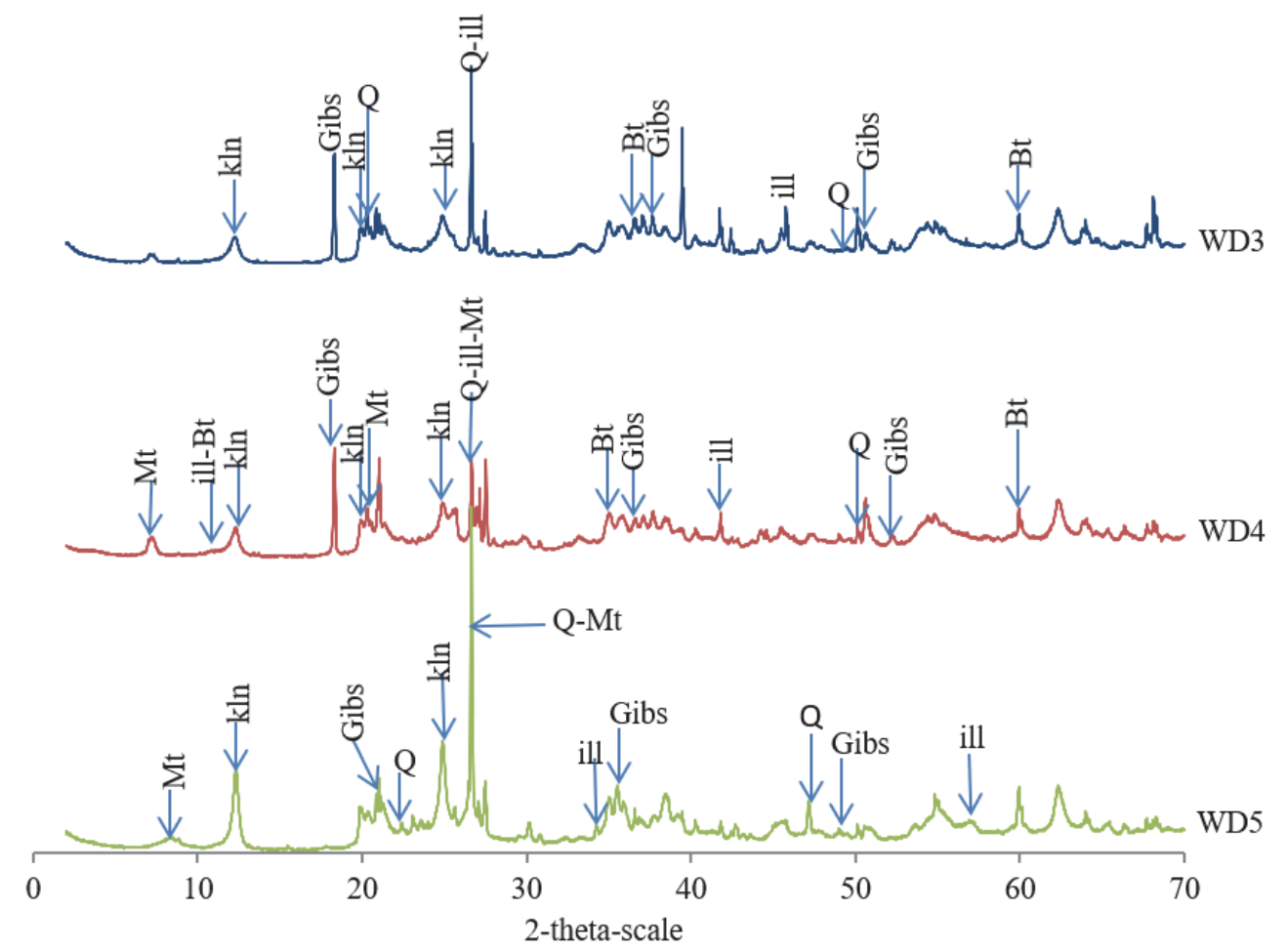

Figure 8. XRD patterns of mineral constituents of Ofen Tiben weathered materials

$\mathbf{i l l}=$ illite. $\mathbf{K} \mathbf{I n}=$ kaolinite. Gibs=gibbsite. $\mathbf{Q}=$ quartz. $\mathbf{H e m}=$ hematite. $\mathbf{M t}=$ montmorillonite. $\mathbf{B t}=$ biotite.

Finally, the X-ray diffraction mineralogical analysis on weathered materials of Ogwei Tiben (figure. 9) indicates that upper assemblage consists of phyllitic minerals (kaolinite, illite, montmorillonite, biotite and muscovite) and associated minerals (goethite and quartz). Meanwhile, the lower assemblage consists of phyllitic minerals (kaolinite, illite, biotite and montmorillonite) and associated minerals (quartz).

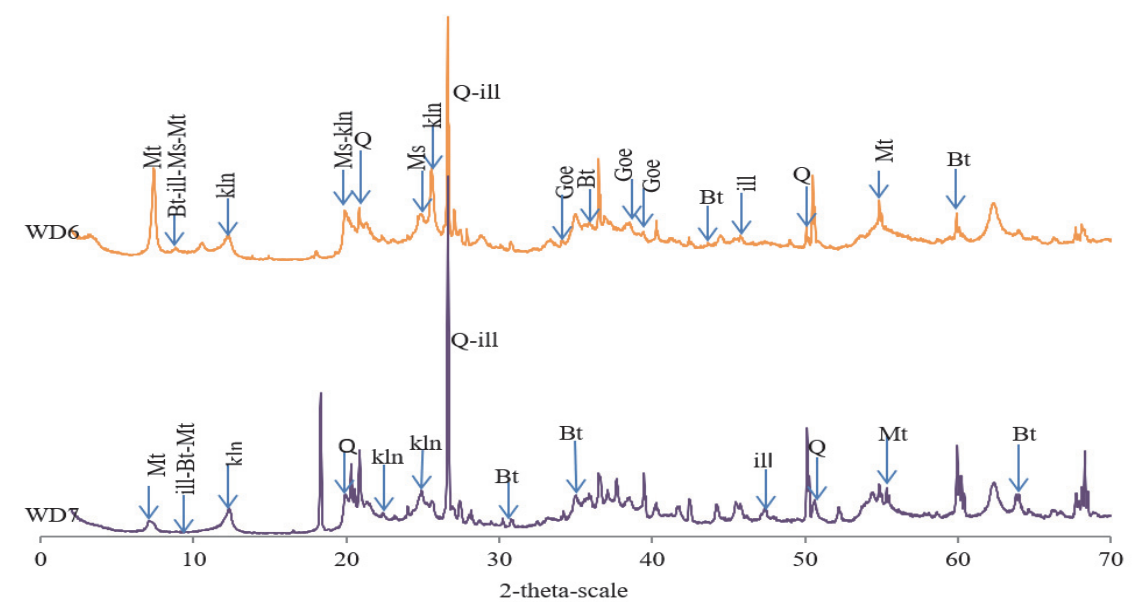

Figure 9. XRD patterns of mineral constituents of Ogwei Tiben weathered materials.

ill=illite. $\quad$ Kln=kaolinite. $\quad$ Gibs=gibbsite. $\quad \mathbf{Q}=$ quartz. $\quad \mathbf{H e m}=$ hematite. $\quad \mathbf{M t}=$ montmorillonite. $\quad \mathbf{B t}=$ biotite. Goe $=$ goethite. $\mathbf{M s}=$ muscovite.

The X-ray diffraction mineralogical analysis on weathered materials of Fifty One, Ofen Tiben and Ogwei Tiben 
are summarized in table 1 below.

Table 1. X-ray diffraction mineralogical composition

\begin{tabular}{llcc}
\hline Localities & \multicolumn{3}{c}{ Mineralogical composition } \\
\hline \multirow{3}{*}{ Fifty One } & & Phyllitic minerals & Associated minerals \\
\cline { 2 - 4 } & WD1 & Gibs; Kln & Q; Hem; Goe \\
\cline { 2 - 4 } Ofen Tiben & Kln; ill; Bt; Ms & Q \\
\cline { 2 - 4 } & WD3 & Gibs; Kln; ill; Bt & Q \\
\cline { 2 - 4 } & WD4 & Gibs; Kln; ill; Mt; Bt & Q \\
\hline Ogwei Tiben & WD6 & Gibs; Kln; ill; Mt & Klll; Mt; Ms; Bt \\
\cline { 2 - 4 } & WD7 & Kln; ill; Mt; Bt & Q; Goe \\
\hline
\end{tabular}

\subsection{Geotechnical Characteristics}

The geotechnical characteristics on weathered materials of Fifty One, Ofen Tiben and Ogwei Tiben are summarized in table 2 below. These geotechnical characteristics are essential for the slope stability analysis according to Closset \&Wojtkowiak (1993).

Table 2. Geotechnical characteristics of Widikum soil and its surroundings

\begin{tabular}{|c|c|c|c|c|c|c|c|c|c|c|c|c|c|c|c|}
\hline SP & $\begin{array}{c}\mathrm{W} \\
(\%)\end{array}$ & $\mathrm{w}_{\mathrm{l}}$ & $\mathrm{w}_{\mathrm{p}}$ & $I_{p}$ & $\begin{array}{r}n \\
(\%) \\
\end{array}$ & $\begin{array}{r}\mathrm{e} \\
(\%) \\
\end{array}$ & $\begin{array}{l}\leq 80 \mu \mathrm{m} \\
(\%)\end{array}$ & $\begin{array}{l}\gamma \\
\left(\mathrm{kN} / \mathrm{m}^{3}\right)\end{array}$ & $\begin{array}{c}\gamma_{\mathrm{d}} \\
\left(\mathrm{kN} / \mathrm{m}^{3}\right)\end{array}$ & $\begin{array}{c}\gamma_{\mathrm{s}} \\
\left(\mathrm{kN} / \mathrm{m}^{3}\right)\end{array}$ & $\begin{array}{l}\mathrm{Sr} \\
(\%)\end{array}$ & $\begin{array}{l}\mathrm{Cu} \\
\left(\mathrm{kN} / \mathrm{m}^{2}\right)\end{array}$ & $\begin{array}{l}\varphi \\
\left({ }^{\circ}\right)\end{array}$ & $\begin{array}{l}\mathrm{H}_{\mathrm{c} 1} \\
(\mathrm{~m})\end{array}$ & $\mathrm{H}_{\mathrm{c} 2}$ \\
\hline WD1 & 27.8 & 59.4 & 41.5 & 17.9 & 43.1 & 1.24 & 95 & 15.2 & 11.9 & 26.7 & 60 & 10 & 16.7 & 2.3 & 2.3- \\
\hline WD2 & 28.3 & 64 & 38.7 & 25.3 & 33.8 & 0.94 & 61 & 17.8 & 13.9 & 26.9 & 81 & 34 & 16.25 & 6.8 & $0.13 q$ \\
\hline WD3 & 47.4 & 62.6 & 44.1 & 18.5 & 57 & 1.32 & 95 & 17.0 & 11.5 & 26.7 & 96 & 16 & 20.40 & 5.2 & \\
\hline WD4 & 46.7 & 60.6 & 44.2 & 16.4 & 58 & 1.37 & 97 & 16.5 & 11.3 & 26.7 & 90 & 15 & 5.68 & 29.6 & \\
\hline WD5 & 42.9 & 63.2 & 42.7 & 20.5 & 56 & 1.27 & 78 & 16.8 & 11.8 & 26.7 & 90 & 19 & 9.59 & 5.1 & \\
\hline WD6 & 30 & 71.9 & 42.5 & 29.3 & 33.2 & 0.95 & 66 & 17.7 & 13.6 & 26.5 & 84 & 30 & 19.67 & 6.4 & \\
\hline WD7 & 27 & 59.6 & 39.9 & 19.7 & 31.5 & 0.86 & 67 & 18.3 & 14.3 & 26.7 & 86 & 32 & 12.59 & 16.7 & \\
\hline
\end{tabular}

$\mathbf{S P}=$ sample. $\mathbf{w}=$ water content. $\mathbf{w}_{\mathbf{l}}=$ liquid limit. $\mathbf{w}_{\mathbf{p}}=$ plasticity limit. $\mathbf{I}_{\mathbf{p}}=$ plasticity index. $\mathbf{n}=$ porosity. $\mathbf{e}=$ void ratio. $\gamma=$ unit weigth. $\gamma_{\mathbf{d}}=$ dry unit weigth. $\gamma_{\mathrm{s}}=$ absolute unit weigth. $\mathbf{S r}=$ saturation ratio. $\mathbf{C u}=$ internal cohesion. $\boldsymbol{\varphi}=$ friction angle and $\boldsymbol{H}_{\boldsymbol{c}}$ the critical height.

As seen in this table, the average natural water content varies from 27 to $47.4 \%$. The liquid limit ranges between 59.4 and $71.9 \%$. Hence, the plasticity index falls within 17.9 and $29.3 \%$. The porosity varies between 31.5 to $58 \%$. The saturation ratio varies from 60 to $96 \%$. The grain size particles $\leq 80 \mu \mathrm{m}$ lies between 66 and $97 \%$. The cohesion ranges between 10 to $34 \mathrm{kN} / \mathrm{m}^{2}$. Concerning the friction angle, their values lie between 5.68 to $20.40^{\circ}$.

\section{Interpretation and Discussion of Results}

\subsection{Contribution of the Mineralogical Study}

The weathered materials of Widikum and its surroundings are mainly made up of illite and montmorillonite. Montmorillonite has the smallest crystals and largest surface which aid in increasing its adsorptive capacity (Bailey et al., 1999). Clayed minerals can cause swelling and consequently the change or variation of the mechanical characteristics of the materials (Pejon et al., 1997).Therefore, the potential of clay swelling depends on the texture and structure of its constituents. Moreover, the presence of a weathered clay formation underneath the sliding horizon can constitute a slip surface whose mechanical characteristics further degenerates in the presence of water and constitutes a destabilization factor (Bureau de Recherches Géologiques et Minières [BRGM], 2009). These phenomena of swelling and shrinkage cause many hazards to civil engineering structures. The study of clay behavior is an important factor which can contribute towards improving the mastery and utilization of these clays and mitigate their undesirable effects on infrastructure founded on it. In the same way, rainfalls constitute the principal triggering factor. Hence, it results in infiltration causing firstly an increase in the water contents, resulting in a decrease of the mechanical resistance of certain clay soils and secondly a rise in the soil water table pitting the 
aquifers under pressure triggering the detachment of potential unstable soil masses (BRGM, 2009). Generally, when the proportion of the clay particles exceeds $30 \%$, the weathering materials are regarded as clay (Xiang, 1999). However, the Widikum and its surroundings grain size particles $\leq 80 \mu \mathrm{m}$ lies between 66 and $97 \%$ greater than $35 \%$ thus attesting their clayey character.

\subsection{Contribution of the Geotechnical Study}

The Widikum locality and its surroundings enjoys an equatorial "Guinean" climate type characterized by the abundance of rainfall ( $p=2703.32 \mathrm{~mm}>1500 \mathrm{~mm} /$ year) (Olivry, 1986). However, water plays a principal role in the slope stability due to their infiltration in weathered products (Philliponnat \& Hubert (1997); Flageollet et al. 1999; Iverson, 2000; Meisina, 2006; Tofani et al. 2006). The natural water content of weathered materials vary between 27 and $47.4 \%$ which are close to or even lower than the liquid limit included between 59.4 and $71.9 \%$ which could justify their unstable character. In addition, an increase in the water content reduces the cohesion of clay materials (Avenard, 1962) and stimulates landslide (Neboit, 1991; Grandjean et al. 2006). The poor mechanical characteristics of weathered products are made up of soils susceptible to provoke sliding (Garczynski, 1984). Furthermore, the high plasticity index with values varying between 17.9 and $29.3 \%$ indicates plastic materials and thus very sensitive to creep. The saturation ratio is very high. It comprises between 60 and $96 \%$. For the majority of samples, the saturation ratio is close to $70 \%$ thus attesting their quasi saturated state. Finally, the weathered products are characterized by a low cohesion ranging between 10 and $34 \mathrm{kN} / \mathrm{m}^{2}$ and a relatively low friction angle varying between 9.59 and $20.40^{\circ}$.

\section{Conclusion and Recommendation}

The main purpose of this study was to analyze the stability of Widikum and its surroundings cut slopes by means of the mineralogical and geotechnical studies and to propose suitable remediable solutions. The Fifty One and Ogwei Tiben sites needs some remedial work carried out which entails reducing the slope height and to support it with retaining structures built of basalt hardcores to reduce the effet of slope erosion and also provision should be made for subhorizontal drains to facilitate the drainage of water. The planting of trees especially eucalyptus as well as vertiva grass is recommended at all sites to facilitate the process of evapotranspiration which will render the soil more dried and the roots will also reinforce the soil and thus reduce the incidences of soil slip. Since the least critical height of the steps guarantees more safety and facilitates the execution of the maintenance work, the slope of Ofen Tiben must undergo a height reduction and it's reshaping in steps according to a height of $2.3 \mathrm{~m}$ on the basis of data of table 1 when the platforms do not carry a surcharge. Therefore, it is recommended to adopt a bench of $3 \mathrm{~m}$ and an inclination of $\beta=37.5^{\circ}$. However, if the platforms are intended to carry surcharge when executing slope works, the critical height must be calculated using the expression $\mathrm{H}_{\mathrm{c} 2}=2.3-0.13 \mathrm{q}$. Moreover, if more water still noticed, oozing out the slope surfaces, then it is necessary to carry out gabions works at the base of the slopes made of basalt or granite hardcore with a minimum thickness of $0.8 \mathrm{~m}$.

\section{Acknowledgments}

This work was carried out in collaboration of all authors. Authors ORMK, ASLW and FN designed the study, performed the mineralogical and geotechnical characterization of the cut slopes of Widikum and its surroundings, wrote the protocol and wrote the first draft of the manuscript. Author VYK corrected the first draft and last version. All authors read and approved the last version. The authors thank M. Philippe NOUANGA, the Director of National Laboratory of Civil Engineering of Yaounde-Cameroon (LABOGENIE) and the researchers of this structure, who permitted us to carry out the geotechnical analysis of which the results are here in presented.

\section{References}

Avenard, J. M. (1962). La solifluxion ou quelques méthodes de mécanique des sols appliquées au problème géomorphologique des versants. Mémoire de la revue de Géomorphologie dynamique, n1. Édit. SEDES, Paris, $164 p$.

Bailey, S. E., Olin, T. J., Bricka, R. M., \& Adrian, D. D. (1999). A review of potentially low-cost sorbents for heavy metals. Water Research, 33(11), 2469-2479.

BRGM. (2009). Cartographie de l'aléa mouvement de terrain sur la commune d'Ars-sur-Moselle. Rapport final/RP-57263. Juin 2009.

Closset, L., \& Wojtkowiak, F. (1993). Géotechnique appliquée à la sécurité des exploitations à ciel ouvert en terrains alluvionnaires. $B R G M$, service sol et soul-sol. Direction de l'ingénierie géotechnique.

Delmas, P., Cartier, G., \& Pouget, P. (1987). Méthodes d'analyse des risques liés aux glissements de terrain. Bull. Liaison labo Pet Ch. Juil-Aout/Sept-Oct. 150-151. 
Feng, X. T., Li, S. J., Zhao, H. B., Zhang, W. G., \& Liang, Y. (2004). Intergrated intelligent methodology for larges-cale landslide prevention design. Inter. Jour. of rock Mechanics and Mining Sciences, 41, 1-6.

Flageollet, J. C., Maquaire, O., Martin, B., \& Weber, D. (1999). Landslides and climatic control conditions in the Barcelonnette and Vars basins (SouthernFrench Alps, France).

Garczynski, F. (1984). Glissement de terrain et foret de montagne. Grenoble. Service de Restauration des terrains en Montagne. 23p.

Grandjean, G., Bitri, G.A., Pennetier, O., Meric, J. P., \& Malet, J. P. (2006). Caractérisation de la structure interne et de l'état hydrique de glissements argilo-marneux par tomographie géophysique : l'exemple du glissementcoulée de Super-Sauze. C.R. Geoscience, 338, 587-595.

Iverson, R. M. (2000). Landslide triggering by rain infiltration. Water Resources Research, 36(7), 1897-1910.

Kouayep, L. S., Medjo, E. R., Kamgang, K. B. V., Wouatong, A. S. L., \& Ngapgue, F. (2009). The influence of rainfall on mass movements: The case of Bana, West Cameroon, ISEV2009-Environmental Vibration: Prediction, Monitoring, Mitigation and evaluation. Science Press. Beijing, 1, 822-829.

Li, X. L. (1999). Comportement hydromécanique des sols fins: de l'état saturé à l'état non saturé. Thèse de Doctorat en Sciences Appliquées, Université de Liège. 375p.

Lulseged, A., Hiromitu, Y., Hideaki, M., \& Tkami, K. (2005). Landslides in Sado Island of Japan: Part I. Case studies, monitoring techniques and environmental consideration. Engineering Geology, 84, 419-431.

Meisina, C. (2006). Characterisation of weathered clayey soils responsible for shallow landslides. Natural Hazards and Earth System Sciences, 6(5), 825-838.

Neboit, R. (1991). L'homme et l'érosion. L'érosion des sols dans le monde. Publications de la Faculté des Lettres de Clermont-Ferrand II, n 34, 269p.

Norm NF P 94-050. (1995). Soils, recognition and tests: determination of natural water contents.

Norm NF P 94-051. (1993). Soils, recognition and tests: determination of the Atterberg limits.

Norm NF P 94-054. (1991). Soils, recognition and tests: determination of Absolute density.

Norm NF P 94-074. (1994). Soils, recognition and tests: determination of triaxial shear.

Olivry, J. C. (1986). Fleuves et rivières du Cameroun. MESRESORSTOM, ISBN, 2-7099-0804-2, 722 p.

Pejon, O. J, Leroux, A., \& Guignard, D. (1997). Comportement à l'eau des roches argilo-marneuses, suivi du gonflement, importance de la minéralogie et des textures. Bulletin de l'association internationale de géologie de l'ingénieur, Paris, 55, 105-119.

Philipponnat, \& Hubert (1997). Fondations et ouvrages en terre. Editions Eyrolles, $3^{\text {ème }}$ édition.

Picarelli, L., Urciuoli, G., \& Russo, C. (2004). The role of ground water regime on behavior of clay slopes. Canadian Geotechnical Journal, 41, 467-484.

Tofani, V., Dapporto, S., Vannocci, P., \& Casagli, N. (2006). Infiltration, seepage and slope instability mechanisms during the 20-21 November 2000 rainstorm in Tuscany, central Italy. Natural Hazards and Earth System Science, 6(6), 1025-1033.

Zangmo T. G., Kagou, D. A., Nkouathio, D. G., \& Wandji, P. (2009). Typology of natural hazards and assessment of associated risks in the mount Bambouto caldera (Cameroon line, West Cameroon), Acta Geological Sinica (English Edition), 83(5), 1008-1016.

\section{Copyrights}

Copyright for this article is retained by the author(s), with first publication rights granted to the journal.

This is an open-access article distributed under the terms and conditions of the Creative Commons Attribution license (http://creativecommons.org/licenses/by/4.0/). 